\title{
Effect of High-Temperature Curing Methods on the Compressive Strength Development of Concrete Containing High Volumes of Ground Granulated Blast-Furnace Slag
}

\author{
Wonsuk Jung ${ }^{1}$ and Se-Jin Choi $^{2}$ \\ ${ }^{1}$ School of Mechanical Engineering, Chungnam National University, Daejeon, Republic of Korea \\ ${ }^{2}$ Department of Architectural Engineering, Wonkwang University, 460 Iksan-daero, Iksan 54538, Republic of Korea \\ Correspondence should be addressed to Se-Jin Choi; csj2378@wku.ac.kr
}

Received 17 March 2017; Accepted 27 June 2017; Published 26 July 2017

Academic Editor: Xiao-Yong Wang

Copyright (C) 2017 Wonsuk Jung and Se-Jin Choi. This is an open access article distributed under the Creative Commons Attribution License, which permits unrestricted use, distribution, and reproduction in any medium, provided the original work is properly cited.

\begin{abstract}
This paper investigates the effect of the high-temperature curing methods on the compressive strength of concrete containing high volumes of ground granulated blast-furnace slag (GGBS). GGBS was used to replace Portland cement at a replacement ratio of $60 \%$ by binder mass. The high-temperature curing parameters used in this study were the delay period, temperature rise, peak temperature (PT), peak period, and temperature down. Test results demonstrate that the compressive strength of the samples with PTs of $65^{\circ} \mathrm{C}$ and $75^{\circ} \mathrm{C}$ was about $88 \%$ higher than that of the samples with a PT of $55^{\circ} \mathrm{C}$ after 1 day. According to this investigation, there might be optimum high-temperature curing conditions for preparing a concrete containing high volumes of GGBS, and incorporating GGBS into precast concrete mixes can be a very effective tool in increasing the applicability of this by-product.
\end{abstract}

\section{Introduction}

About 14 million tons of blast-furnace slag, the by-product of steel industry, is produced annually in Korea [1]. Ground granulated blast-furnace slag (GGBS), either as a constituent of cement or as a mineral admixture, is widely used to make not only traditional concrete but also high-performance concrete, which has several advantages including workability, long-term strength, and durability [2]. Recently, to reduce $\mathrm{CO}_{2}$ production in the cement and concrete industry, many studies have been conducted on environmentally friendly concrete with high-volume supplementary cementitious materials [3-9]. It was reported [10-12] that concrete using GGBS has the advantage of an earlier strength development under high-temperature curing conditions owing to the temperature-dependent characteristic of GGBS. Owing to this, GGBS might be effectively used in preparing precast concrete manufactured with high-temperature curing.

While significant literature is available on supplementary cementitious materials in concrete, such as GGBS and fly ash, few works have studied the effect of high-temperature curing conditions on the strength properties of concrete containing high-volume supplementary cementitious materials [11, 13-15]. Miura and Iwaki [11] evaluated the strength development of concrete incorporating high levels of GGBS at low temperatures, demonstrating that GGBS concrete with a specific surface area of $400 \mathrm{~m}^{2} / \mathrm{kg}$ faces serious strength development problems at early ages and with low curing temperatures. Aldea et al. [13] investigated the effects of curing conditions on the properties of concrete prepared with slag replacement. Test results indicated that slag replacement of up to $50 \%$ by mass had little effect on strength and steam curing reduced the compressive strength as compared to other curing types (such as autoclaving and normal curing). Yazici et al. [14] investigated the effect of steam curing on class $\mathrm{C}$ high-volume fly ash concrete mixtures, indicating that steam curing accelerated the 1-day strength development but the long-term strength was greatly reduced. Liu et al. [15] evaluated the influence of steam curing on the compressive strength of concrete containing supplementary cementing 


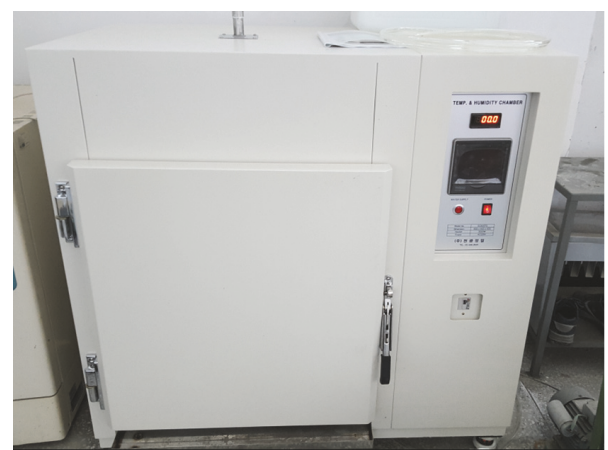

FIGURE 1: Autotemperature-controlled curing chamber.

materials. Test results indicated that the concrete containing ultrafine fly ash (UFA) had a low early strength after 13 hours of steam curing and the difference between the 28-day compressive strength of 13-hour steam-cured concrete and that of moist-cured concrete was large.

This study examines how the compressive strength of concrete containing high volumes of GGBS is affected by various high-temperature curing methods. To date, the compressive strength development of high-volume GGBS concrete according to various high-temperature curing conditions-including delay period, temperature rise, peak temperature and period, and temperature down-has not been reported. The goal of this work is to demonstrate how GGBS can be used more efficiently and effectively in precast concrete using high-temperature curing methods.

\section{Materials and Methods}

2.1. Materials. ASTM Type I Portland cement with a specific gravity of 3.15 and crushed gravel with a specific gravity of 2.67 and fineness modulus of 6.75 were used. The fine aggregates used were crushed sand and washed sea sand (specific gravities of 2.62 and 2.66, resp.), which are commonly used in Korea. GGBS with a specific gravity of 2.89 and Blaine fineness of $4490 \mathrm{~cm}^{2} / \mathrm{g}$ was obtained from Po-hang, South Korea. The chemical composition of the cement and GGBS, determined by X-ray fluorescence, is shown in Table 1.

2.2. Mix Proportions and Specimen Preparation. In this study, GGBS was used to replace Portland cement at a replacement ratio of $60 \%$ by binder mass. A constant water-to-binder ratio $(w / b)$ of 0.35 was used in this investigation. The mix proportions are given in Table 2.

Concrete was mixed in a twin shaft mechanical mixer. Specimens were cast in a cylindrical mold (100 mm diameter, $200 \mathrm{~mm}$ length) for the compressive strength test. After casting, the cylinder molds were moved to the autotemperaturecontrolled curing chamber with a $100 \%$ relative humidity, shown in Figure 1, and cured according to various high-temperature curing methods. The samples were then removed from the molds and cured in a water-curing tank before the compressive strength test.

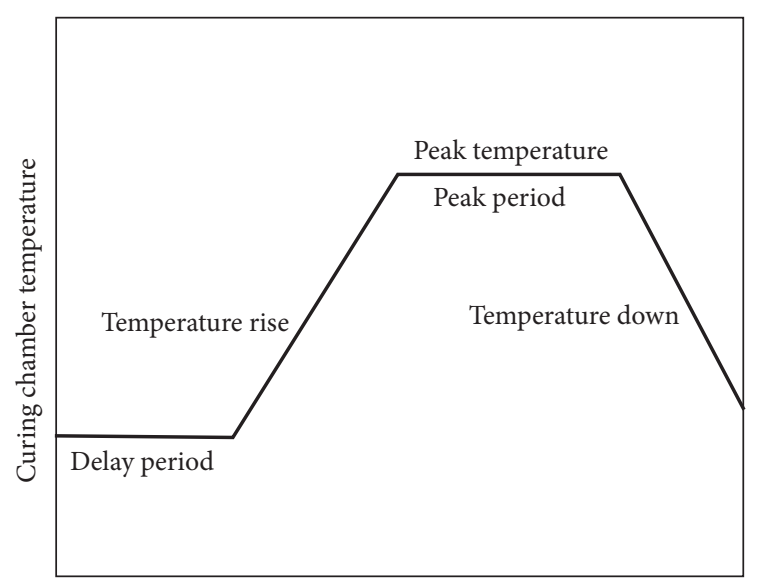

Curing time

FIGURE 2: High-temperature curing cycle.

Figure 2 shows the common high-temperature curing cycle used in manufacturing precast concrete. The hightemperature curing methods used in this investigation involved delay periods (DPs) of 2,3 , and $4 \mathrm{~h}$ at $20^{\circ} \mathrm{C}$; temperature rises (TRs) of 10,15 , and $20^{\circ} \mathrm{C} / \mathrm{h}$; peak temperatures (PTs) of 55,65 , and $75^{\circ} \mathrm{C}$; peak periods (PPs) of 3, 4, and $5 \mathrm{~h}$; and temperature downs (TDs) of 5,10 , and $15^{\circ} \mathrm{C} / \mathrm{h}$. The high-temperature curing methods are detailed in Figure 3 and Table 3. The compressive strength of the concrete was tested after 1, 14, and 28 days, in accordance with ASTM C39. Each strength is the average value of three samples.

\section{Results and Discussion}

3.1. Delay Period and Compressive Strength. The variation in the compressive strength with DP is shown in Figure 4 . The 1-day compressive strength of concrete mixes with DPs of 2, 3 , and $4 \mathrm{~h}$ was $30,32.5$, and $31 \mathrm{MPa}$, respectively. After 14 days, the values for the mixes with a DP of 3 h were about $4.8-8.8 \%$ higher than the other mixes. In addition, the compressive strength of the concrete mix with a DP of $3 \mathrm{~h}$ was greater than the other mixes after 28 days, with a value of $49.5 \mathrm{MPa}$. In contrast, the DP of $2 \mathrm{~h}$ gave the lowest values for each test day. After 28 days, the compressive strength of the $3 \mathrm{~h}$ DP concrete was about $10 \%$ higher than that with a DP of $2 \mathrm{~h}$.

3.2. Temperature Rise and Compressive Strength. The compressive strength variation with TR is given in Figure 5 at different ages. The 1-day compressive strength of the sample with a TR of $15^{\circ} \mathrm{C} / \mathrm{h}$ was $32.5 \mathrm{MPa}$, and this value was higher than that of other samples with a compressive strength of 27 $28 \mathrm{MPa}$. The compressive strength of the $20^{\circ} \mathrm{C} / \mathrm{h}$ TR concrete was $28 \mathrm{MPa}$ after 1 day, about $3.7 \%$ higher than that for the $10^{\circ} \mathrm{C} / \mathrm{h}$ TR concrete. However, the later compressive strength of the $20^{\circ} \mathrm{C} / \mathrm{h}$ TR concrete was $41 \mathrm{MPa}$ (14 days) and $47 \mathrm{MPa}$ (28 days), about $2.1-5.0 \%$ lower than the corresponding values of $10^{\circ} \mathrm{C} / \mathrm{h}$ TR sample. This test results demonstrate that high heating rate might result in an advantageous high early strength development, but a disadvantageous long-term 

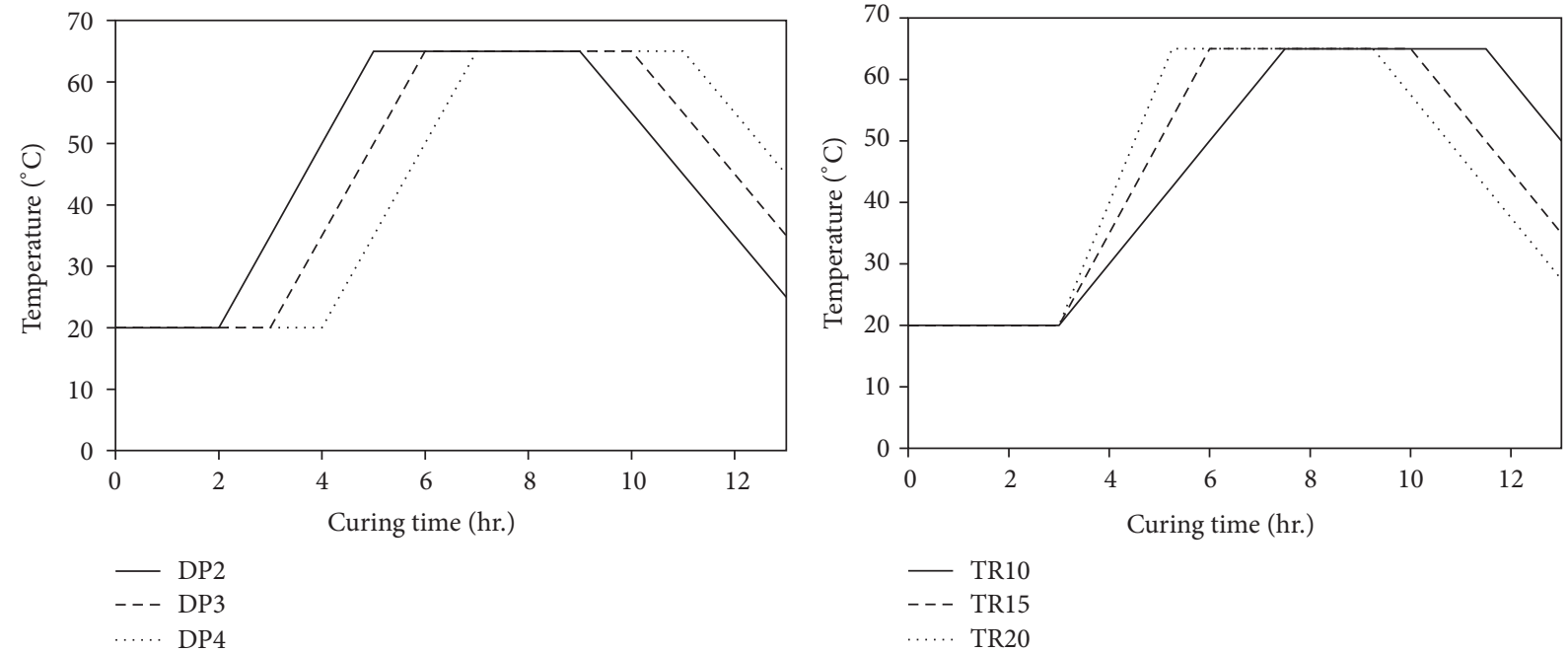

(a) Delay period condition

(b) Temperature rise condition
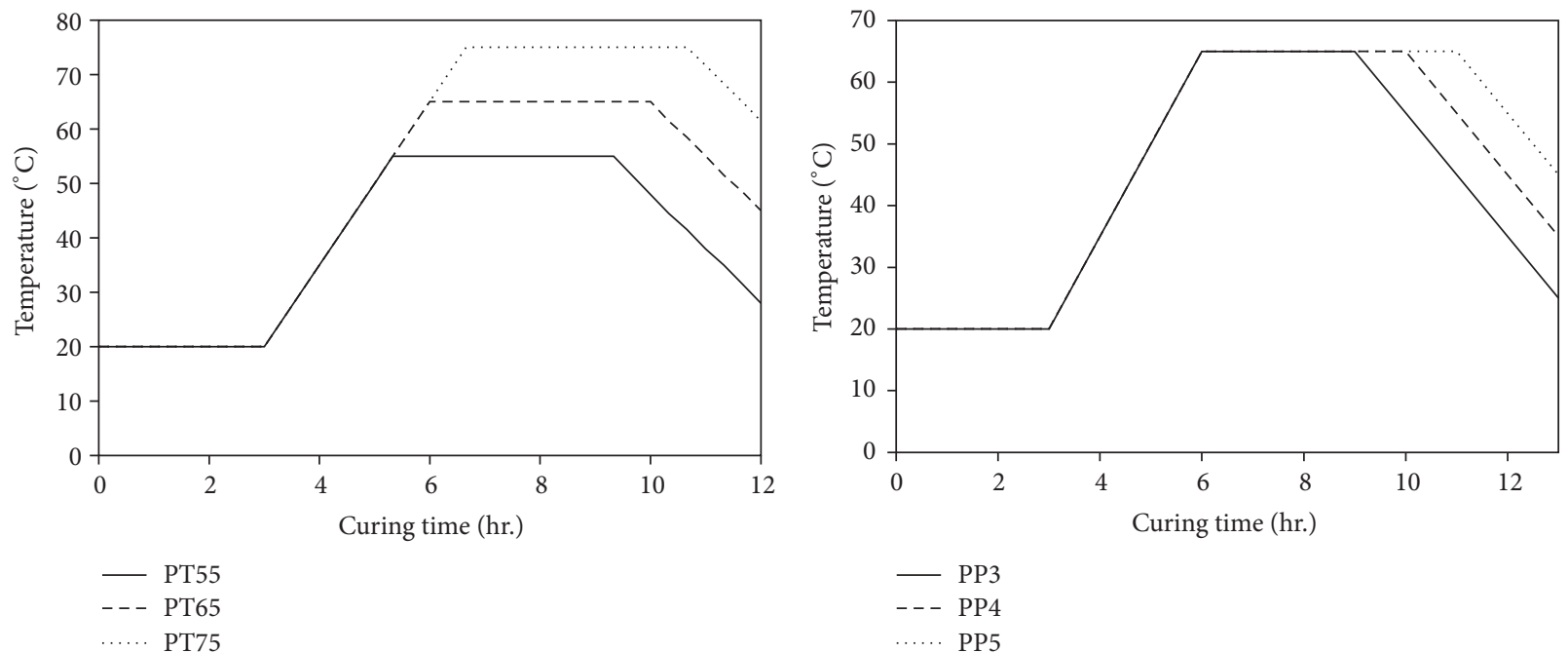

$\begin{array}{ll}\text { — } & \text { PP3 } \\ --- & \text { PP4 } \\ \ldots \ldots & \text { PP5 }\end{array}$

(c) Peak temperature condition

(d) Peak period condition

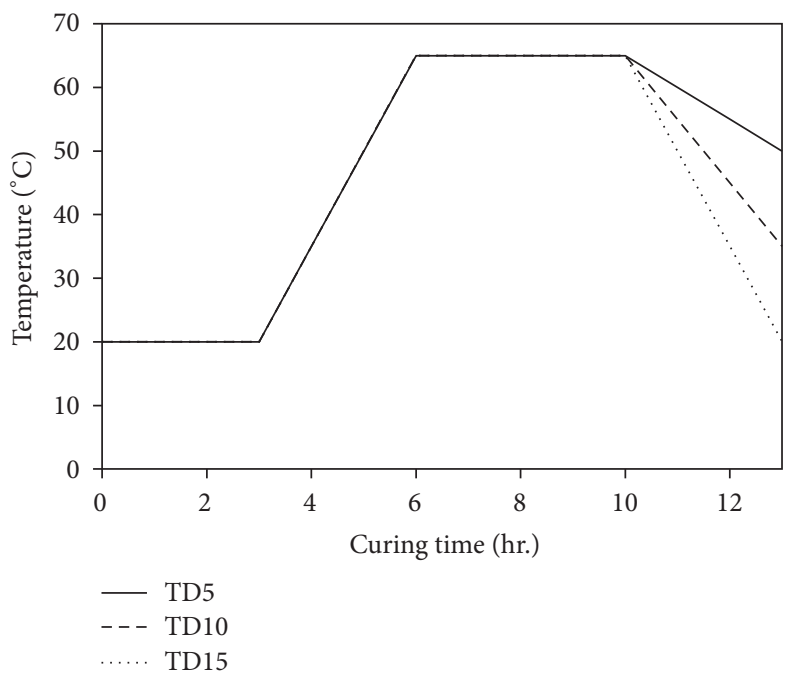

(e) Temperature down condition

FIGURE 3: Various high-temperature curing methods used in this study. 
TABLE 1: Chemical composition of Portland cement and GGBS.

\begin{tabular}{lcccccccc}
\hline Materials & $\mathrm{SiO}_{2}$ & $\mathrm{Al}_{2} \mathrm{O}_{3}$ & $\mathrm{Fe}_{2} \mathrm{O}_{3}$ & $\mathrm{~K}_{2} \mathrm{O}$ & $\mathrm{CaO}$ & $\mathrm{MgO}$ & $\mathrm{Na}_{2} \mathrm{O}$ & $\mathrm{SO}_{3}$ \\
\hline Cement & 21.20 & 4.64 & 2.91 & 1.22 & 61.90 & 1.87 & 0.29 & 2.31 \\
GGBS & 34.00 & 16.40 & 0.50 & 0.45 & 37.20 & 6.29 & 1.33 & 2.71 \\
\hline
\end{tabular}

TABLE 2: Mixture proportions of concrete.

\begin{tabular}{lcccccr}
\hline $\begin{array}{l}\text { W/B } \\
\%\end{array}$ & $\begin{array}{c}\text { Cement } \\
\mathrm{kg} / \mathrm{m}^{3}\end{array}$ & $\begin{array}{c}\text { GGBS } \\
\mathrm{kg} / \mathrm{m}^{3}\end{array}$ & $\begin{array}{c}\text { Water } \\
\mathrm{kg} / \mathrm{m}^{3}\end{array}$ & $\begin{array}{c}\text { Gravel } \\
\mathrm{kg} / \mathrm{m}^{3}\end{array}$ & $\begin{array}{c}\text { Crushed sand } \\
\mathrm{kg} / \mathrm{m}^{3}\end{array}$ & $\begin{array}{c}\text { Sea sand } \\
\mathrm{kg} / \mathrm{m}^{3}\end{array}$ \\
\hline 35 & 168 & 252 & 140 & 1012 & 406 \\
\hline
\end{tabular}

TABLE 3: Steam curing methods.

\begin{tabular}{|c|c|c|c|c|c|}
\hline Curing methods & DP, hours & $\mathrm{TR},{ }^{\circ} \mathrm{C} / \mathrm{h}$ & $\mathrm{PT},{ }^{\circ} \mathrm{C}$ & PP, hours & $\mathrm{TD},{ }^{\circ} \mathrm{C} / \mathrm{h}$ \\
\hline Delay period (DP) & $2,3,4$ & 15 & 65 & 4 & 10 \\
\hline Temperature rise (TR) & 3 & $10,15,20$ & 65 & 4 & 10 \\
\hline Peak temperature (PT) & 3 & 15 & $55,65,75$ & 4 & 10 \\
\hline Peak period (PP) & 3 & 15 & 65 & $3,4,5$ & 10 \\
\hline Temperature down (TP) & 3 & 15 & 65 & 4 & $5,10,15$ \\
\hline
\end{tabular}

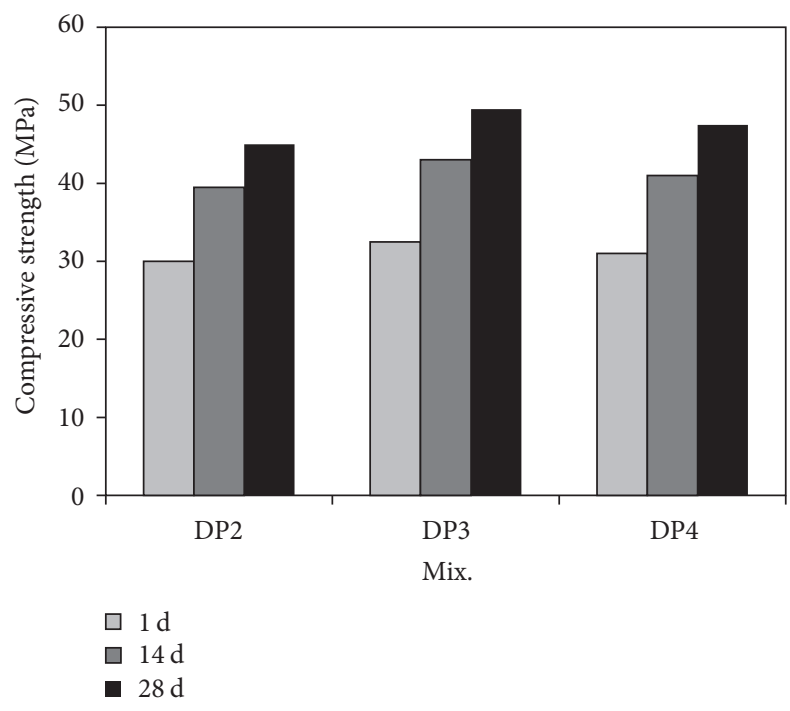

FIGURE 4: Compressive strength versus delay period.

strength development. An earlier study [11] reported that heat curing seems to have an adverse influence on strength development, particularly at later ages.

3.3. Peak Temperature and Compressive Strength. Figure 6 shows the compressive strength variation of concrete mixes with different PTs at different ages. The 1-day compressive strength of the $65^{\circ} \mathrm{C}$ and $75^{\circ} \mathrm{C}$ PT samples was 32.5 and $32 \mathrm{MPa}$, respectively. These values are about $88-91 \%$ higher than that of the sample with the lowest PT of $55^{\circ} \mathrm{C}(17 \mathrm{MPa})$. This result is similar to that of a previous study [10]. Barnett et al. reported that the early-age strength is much more sensitive to temperature for samples with higher levels of GGBS. The

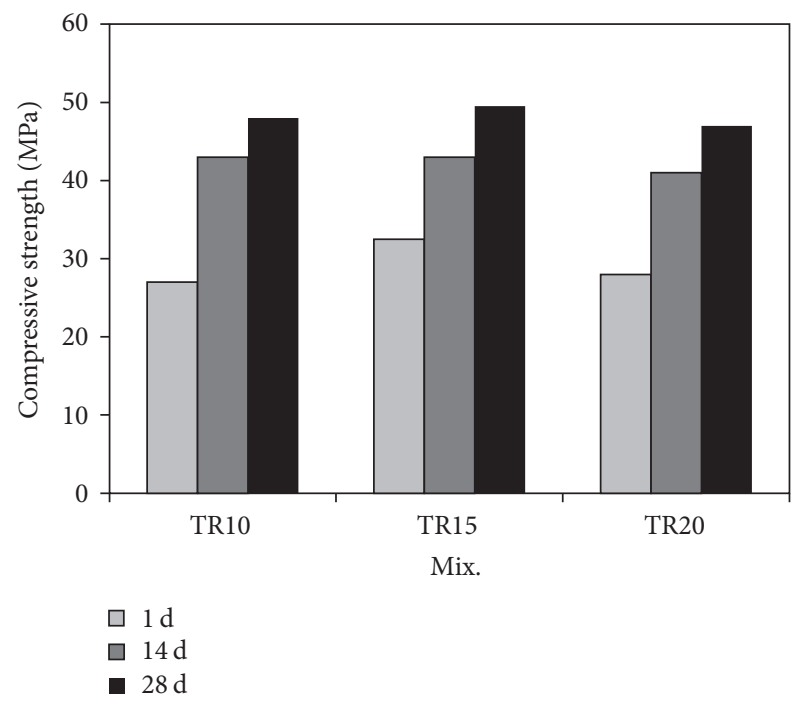

FIGURE 5: Compressive strength versus temperature rise.

lowest 14-day compressive strength was for the sample with a PT of $55^{\circ} \mathrm{C}(36 \mathrm{MPa})$. After 28 days, the compressive strength of the $65^{\circ} \mathrm{C}$ PT concrete was the greatest $(49.5 \mathrm{MPa})$, being about $10-18 \%$ higher than the samples with PTs of $55^{\circ} \mathrm{C}$ and $75^{\circ} \mathrm{C}$.

3.4. Peak Period and Compressive Strength. The variation in compressive strength with PP is given in Figure 7 for different ages. The 1-day compressive strength was highest for the concrete with a PP of $4 \mathrm{~h}$. The 1-day compressive strength values of the samples with PPs of 3,4 , and $5 \mathrm{~h}$ were 25 , 32.5 , and $28 \mathrm{MPa}$, respectively. In addition, after 14 days, the compressive strength of the $4 \mathrm{~h} \mathrm{PP}$ condition was $4.8 \%$ higher 


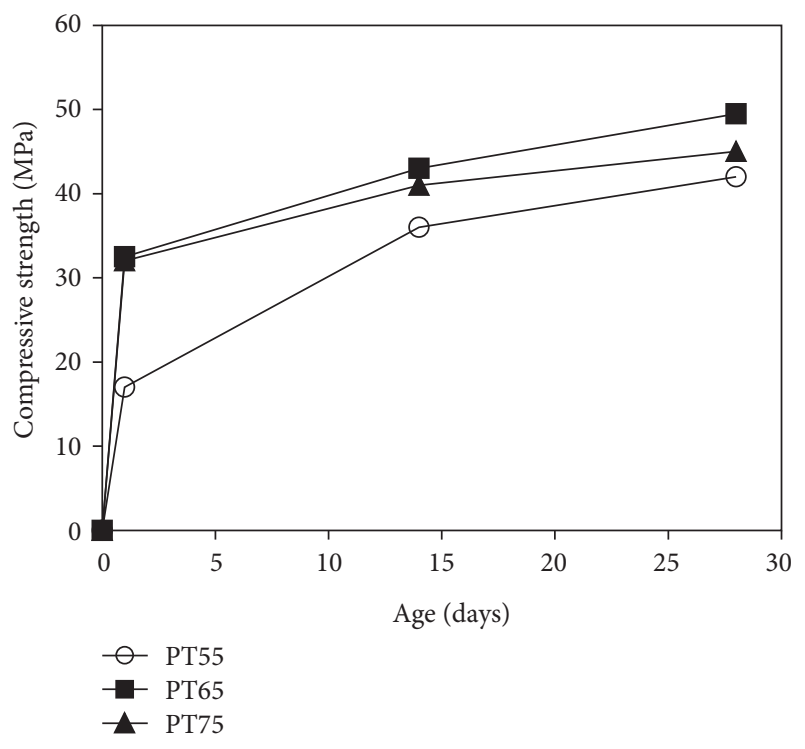

FIGURE 6: Compressive strength versus peak temperature.

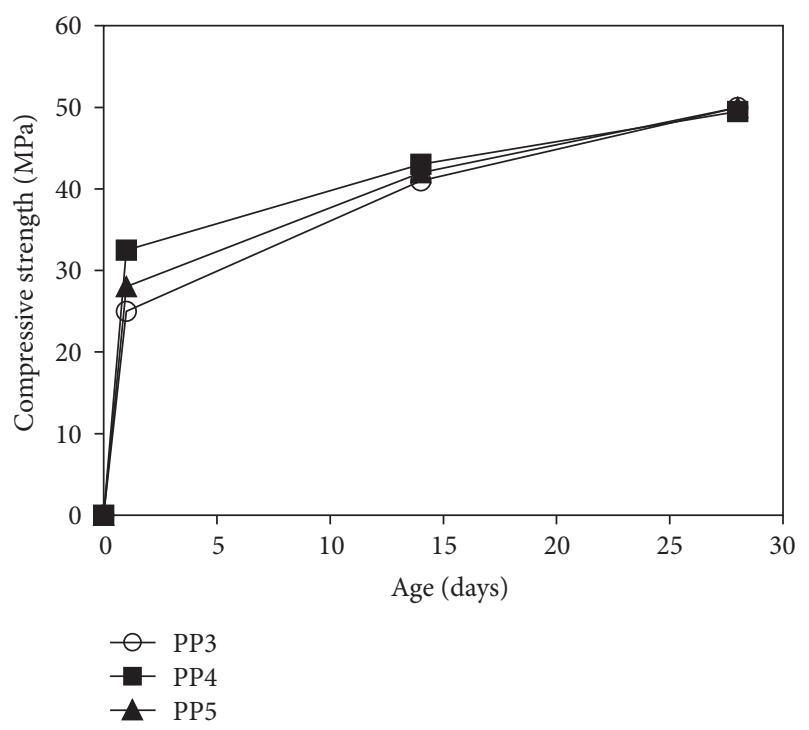

Figure 7: Compressive strength versus peak period.

than that of the concrete with a PP of $3 \mathrm{~h}$. After 28 days, the compressive strengths of all the samples were the same with values ranging from 49.5 to $50 \mathrm{MPa}$.

\subsection{Temperature Down and Compressive Strength. Figure 8} shows the variation in the compressive strength for the concrete with different TD values at different ages. The 1day compressive strength of the concrete with a TD of $5^{\circ} \mathrm{C} / \mathrm{h}$ $\left(35 \mathrm{MPa}\right.$ ) was about $30 \%$ higher than that with a TD of $15^{\circ} \mathrm{C} / \mathrm{h}$. It is assumed that the rapid cooling during steam curing might have a negative influence on the concrete compressive strength at an early age. The compressive strength of the $15^{\circ} \mathrm{C} / \mathrm{h}$ TD condition was $40.5 \mathrm{MPa}$ after 14 days, around $6-11 \%$ lower than the other mixes. However, the compressive

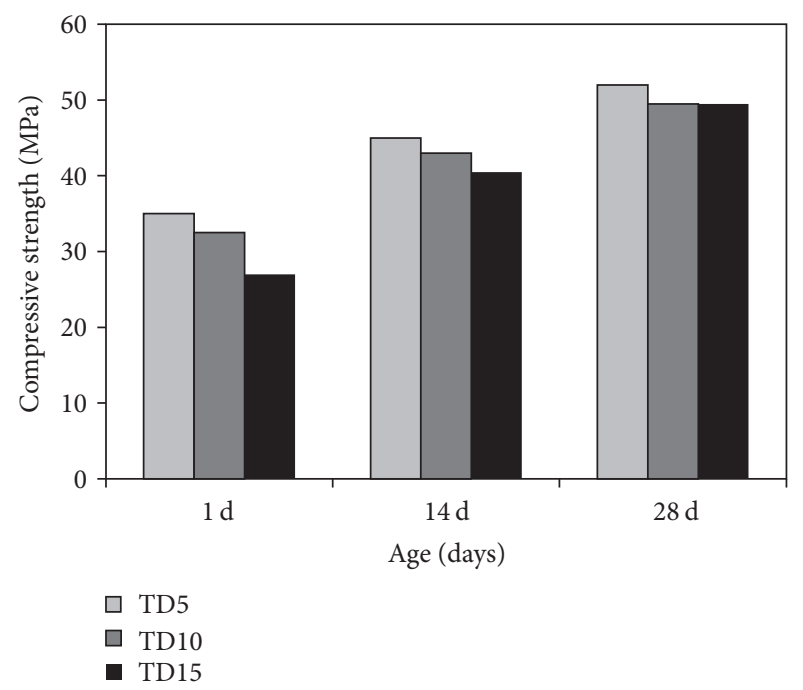

Figure 8: Compressive strength versus temperature down.

strength of the concrete with a TD of $15^{\circ} \mathrm{C} / \mathrm{h}$ was similar to that for the $10^{\circ} \mathrm{C} / \mathrm{h}$ TD condition after 28 days.

\section{Conclusions}

The following conclusions were obtained from the present investigation.

(1) The compressive strength of the concrete mix with a $\mathrm{DP}$ of $3 \mathrm{~h}(49.5 \mathrm{MPa})$ was greater than that of the other mixes after 28 days. In contrast, the compressive strength of the mix with a DP of $2 \mathrm{~h}$ was the lowest value after 28 days.

(2) The compressive strength of the sample with a TR of $20^{\circ} \mathrm{C} / \mathrm{h}$ was about $3.7 \%$ higher than that of the $10^{\circ} \mathrm{C} / \mathrm{h}$ TR sample after 1 day. However, the compressive strength of the sample with $20^{\circ} \mathrm{C} / \mathrm{h}$ TR was lower than that of the sample with a $\mathrm{TR}$ of $10^{\circ} \mathrm{C} / \mathrm{h}$. This demonstrates that the high heating rate might result in an advantageous high early strength development, but a disadvantageous long-term strength development.

(3) The 1-day compressive strength of the samples with PTs of $65^{\circ} \mathrm{C}$ and $75^{\circ} \mathrm{C}$ was about $32 \mathrm{MPa}$, about $88 \%$ higher than the $55^{\circ} \mathrm{C}$ PT condition. After 28 days, the value for the sample with a PT of $65^{\circ} \mathrm{C}$ was the greatest.

(4) The compressive strength of the sample with a PP of $4 \mathrm{~h}$ was $4.8 \%$ higher than that of the $3 \mathrm{~h}$ PP sample after 14 days. After 28 days, the compressive strength of all the samples was the same.

(5) The 1-day compressive strength of the sample with a TD of $5^{\circ} \mathrm{C} / \mathrm{h}$ was about $30 \%$ higher than that with a TD of $15^{\circ} \mathrm{C} / \mathrm{h}$. It is assumed that the rapid cooling during steam curing might adversely affect the compressive strength of the concrete at an early age.

The results of this investigation suggest that there might be optimum high-temperature curing conditions for the preparation of concrete containing high volumes of GGBS. Incorporating GGBS into precast concrete mixes can be a very effective tool in reducing $\mathrm{CO}_{2}$ production in the cement 
industry and increasing the applicability of GGBS. Further studies are needed to establish the relationships between the strength properties of concrete containing high volumes of supplementary cementitious materials and the water-tobinder ratio, mineral admixture type, and so on.

\section{Conflicts of Interest}

The authors declare that there are no conflicts of interest regarding the publication of this paper.

\section{Acknowledgments}

This paper was supported by Wonkwang University in 2015.

\section{References}

[1] Korea Concrete Institute, "Concrete \& Environment," vol.2, Kimoondang, Seoul, Korea, 2016.

[2] K. M. Lee, H. K. Lee, S. H. Lee, and G. Y. Kim, "Autogenous shrinkage of concrete containing granulated blast-furnace slag," Cement and Concrete Research, vol. 36, no. 7, pp. 1279-1285, 2006.

[3] S.-J. Choi and Y.-S. Jeon, "The Fluidity and Hardened Properties of Eco-Friendly Low Cement Concrete with 3 Types of Binders," Journal of the Architectural Institute of Korea Structure \& Construction, vol. 31, no. 11, pp. 63-70, 2015.

[4] H. Yazıc1, "The effect of curing conditions on compressive strength of ultra high strength concrete with high volume mineral admixtures," Building and Environment, vol. 42, no. 5, pp. 2083-2089, 2007.

[5] M.-H. Zhang and J. Islam, "Use of nano-silica to reduce setting time and increase early strength of concretes with high volumes of fly ash or slag," Construction and Building Materials, vol. 29, no. 4, pp. 573-580, 2012.

[6] S.-J. Choi, J.-S. Mun, K.-H. Yang, and S.-J. Kim, "Compressive fatigue performance of fiber-reinforced lightweight concrete with high-volume supplementary cementitious materials," Cement and Concrete Composites, vol. 73, pp. 89-97, 2016.

[7] G. Hannesson, K. Kuder, R. Shogren, and D. Lehman, "The influence of high volume of fly ash and slag on the compressive strength of self-consolidating concrete," Construction and Building Materials, vol. 30, pp. 161-168, 2012.

[8] K. H. Mo, U. Johnson Alengaram, M. Z. Jumaat, and S. P. Yap, "Feasibility study of high volume slag as cement replacement for sustainable structural lightweight oil palm shell concrete," Journal of Cleaner Production, vol. 91, pp. 297-304, 2015.

[9] I. Papayianni and E. Anastasiou, "Production of high-strength concrete using high volume of industrial by-products," Construction and Building Materials, vol. 24, no. 8, pp. 1412-1417, 2010.

[10] S. J. Barnett, M. N. Soutsos, S. G. Millard, and J. H. Bungey, "Strength development of mortars containing ground granulated blast-furnace slag: effect of curing temperature and determination of apparent activation energies," Cement and Concrete Research, vol. 36, no. 3, pp. 434-440, 2006.

[11] T. Miura and I. Iwaki, "Strength development of concrete incorporating high levels of ground granulated blast-furnace slag at low temperature," Materials Journal, vol. 97, no. 1, pp. 6670, 2000.
[12] J. I. Escalante, L. Y. Gómez, K. K. Johal, G. Mendoza, H. Mancha, and J. Méndez, "Reactivity of blast-furnace slag in Portland cement blends hydrated under different conditions," Cement and Concrete Research, vol. 31, no. 10, pp. 1403-1409, 2001.

[13] C.-M. Aldea, F. Young, K. Wang, and S. P. Shah, "Effects of curing conditions on properties of concrete using slag replacement," Cement and Concrete Research, vol. 30, no. 3, pp. 465-472, 2000.

[14] H. Yazici, S. Aydin, H. Yiǧiter, and B. Baradan, "Effect of steam curing on class $\mathrm{C}$ high-volume fly ash concrete mixtures," Cement and Concrete Research, vol. 35, no. 6, pp. 1122-1127, 2005.

[15] B. Liu, Y. Xie, and J. Li, "Influence of steam curing on the compressive strength of concrete containing supplementary cementing materials," Cement and Concrete Research, vol. 35, no. 5, pp. 994-998, 2005. 

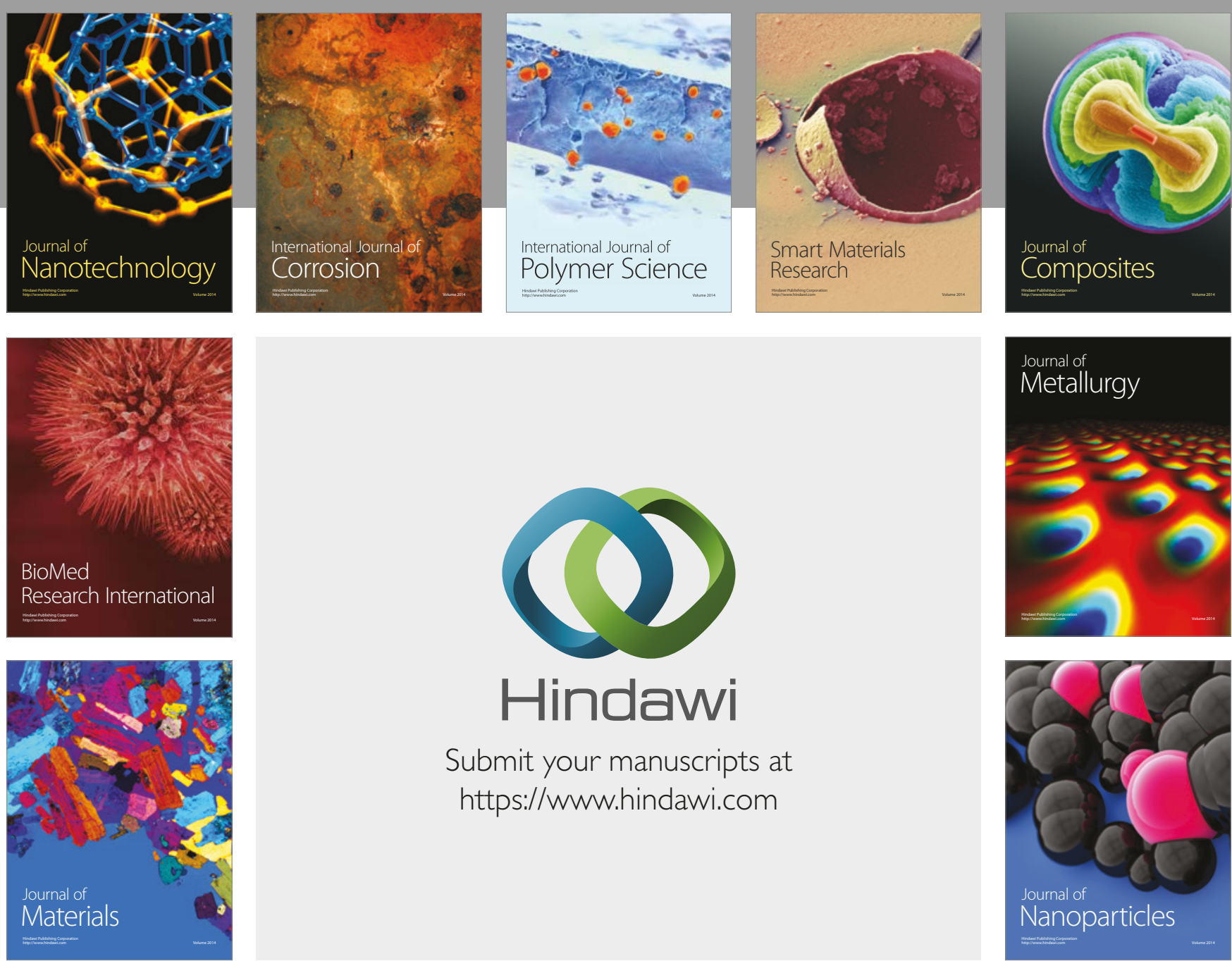

\section{Hindawi}

Submit your manuscripts at

https://www.hindawi.com
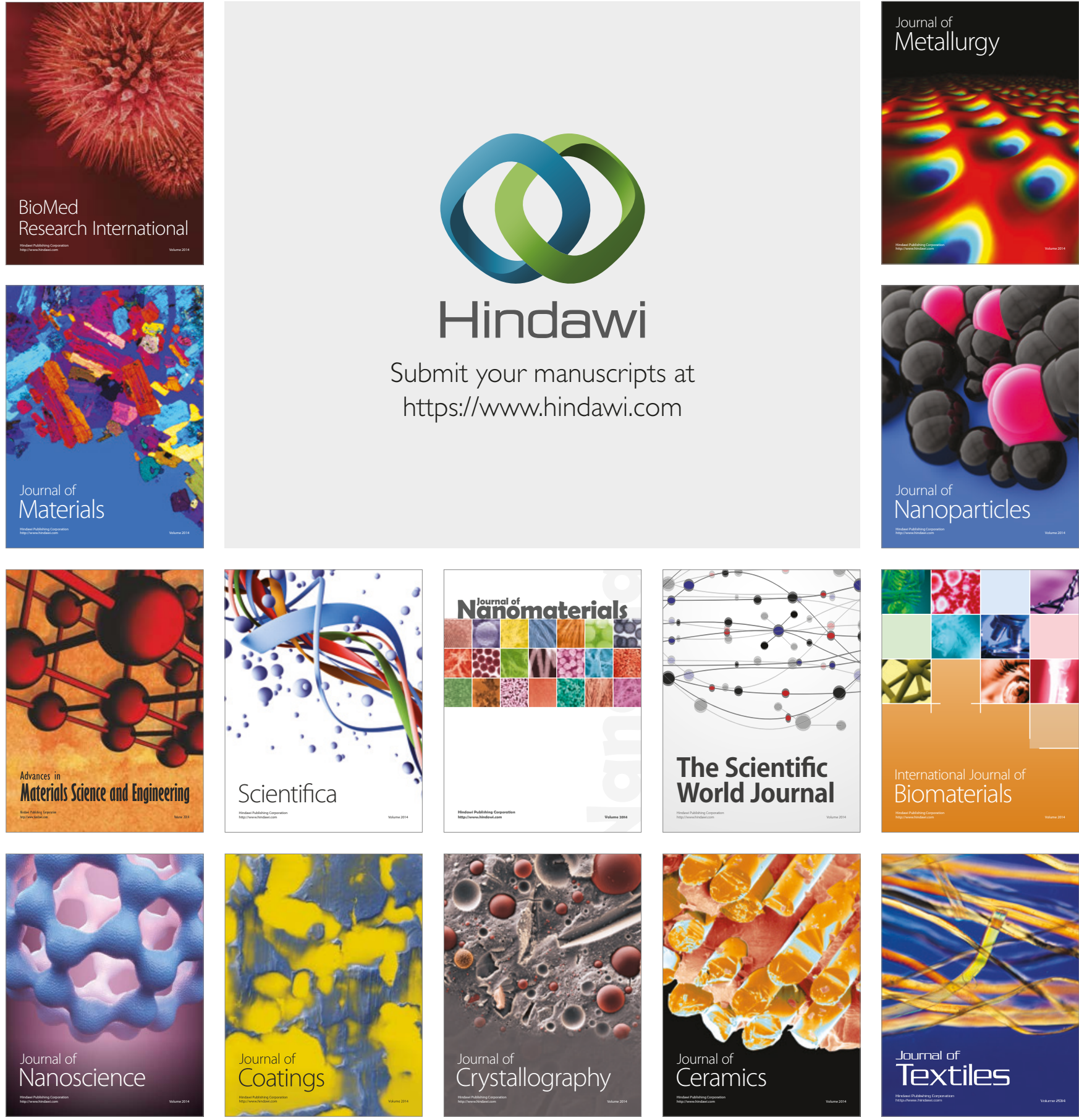

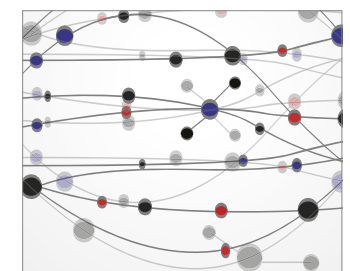

The Scientific World Journal
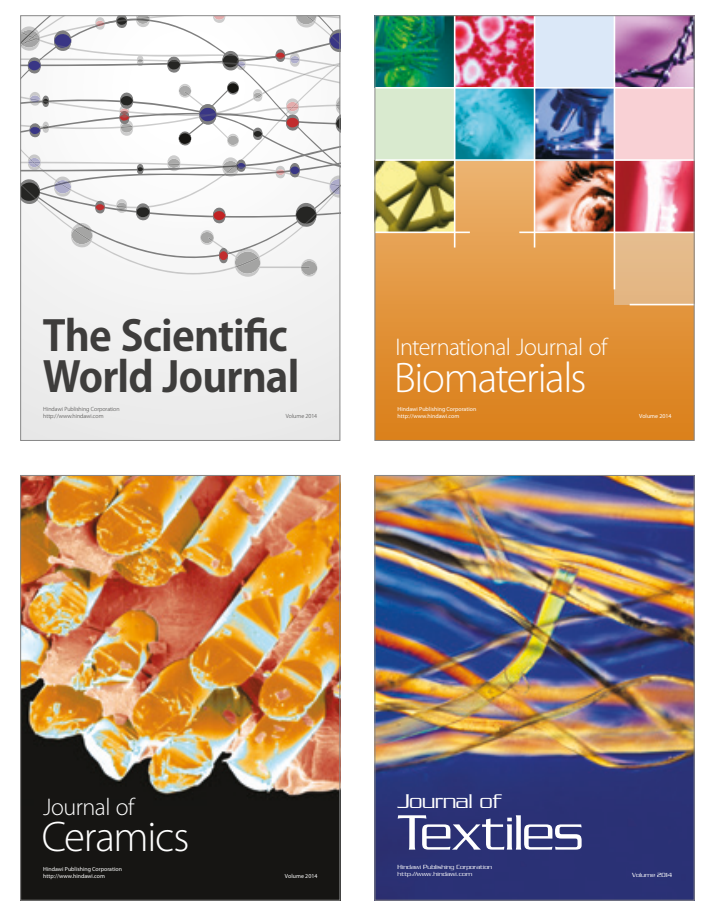